Revista Española de Derecho Internacional

Sección FORO

20. ${ }^{\circ}$ Aniversario del Estatuto de Roma Vol. 70/2, julio-diciembre 2018, Madrid, pp. 217-221

http://dx.doi.org/10.17103/redi.70.2.2018.2a.02

(C) 2018 Asociación de Profesores

de Derecho Internacional

y Relaciones Internacionales

ISSN: 0034-9380; E-ISSN: 2387-1253

\title{
RESTORATIVE JUSTICE AT THE INTERNATIONAL CRIMINAL COURT
}

\author{
Sara KENDALL *
}

With the twentieth anniversary of the Rome Statute of the International Criminal Court (ICC) approaching in July of 2018, the ICC has announced its intention to «mark this milestone» throughout the year, inviting visitors to its website to do the same. An accompanying film commemorating the anniversary opens with scenes of atrocity crimes throughout the world flashing in sequence. Interspersed throughout this account of the Court's establishment are images of victims of crimes that could possibly fall under the court's jurisdiction, whilst the film narrates the subject matter that the ICC is empowered to adjudicate: the use of child soldiers, destruction of cultural property, and sexual violence, among other forms of war crimes, crimes against humanity and genocide. Following a clip of testimony of a survivor of sexual violence crimes, the film introduces the Court's Trust Fund for Victims, which was established through the Rome Statute to provide «support to victims, survivors, their families and community». It closes with the claim that the pursuit of security «starts with justice for everyone». While a familiar genre of institutional self-representation, the film is remarkable for the way in which it foregrounds the figure of the victim of international crimes within a retributive legal field.

I begin from this film as an artefact of commemoration that may reveal how the ICC regards itself twenty years on from its founding through the Rome Statute. In 2022 we will face another Court anniversary, twenty years from when the treaty-based statute came into effect with the required amount of state signatories. While the current anniversary marks the importance of the ICC's formal legal foundation, the latter marks the significance of state support for its mandate, illustrating the longstanding divide in international

* Sara Kendall is Senior Lecturer (Associate Professor) in International Law and Co-Director for Centre for Critical International Law at the University of Kent. Before joining Kent Law School, she was a Researcher in Public International Law at Leiden University and Lecturer in International Relations at the University of Amsterdam. PhD, University of California at Berkeley (S.Kendall@kent.ac.uk). 
legal practice between legal rules and political support for them. In light of the continuing threat of non-compliance, the field of international criminal justice has embraced markers of its continuing vitality and legacy, as illustrated through celebratory events surrounding the recent closures of ad hoc tribunals for Rwanda and the former Yugoslavia ${ }^{1}$. The ICC differs from these two UN-backed tribunals in that it was established with a permanent mandate, and in principle it will continue its work indefinitely. Yet anniversaries provide opportunities for thinking about the Court's contribution to a constellation of objectives, ranging from its most direct aim of holding individual perpetrators of grave crimes to account and developing international criminal law jurisprudence to the more ambitious aims of bringing justice to conflict-affected communities and fostering global security.

If the film shows its audience how the Court seeks to present itself twenty years on from the signing of the Rome Statute, a central feature of this presentation is the role of the victim. As I have argued elsewhere together with Sarah Nouwen, this figure is at least double: the film presents the victim as the beneficiary of the Court's work, a kind of abstraction that serves as the telos or raison d'être of international criminal justice; on the other hand, the Rome Statute constructs the victim as a legal subject, or what we refer to as the «juridified victim ${ }^{2}$. The first figure is invoked by proponents of the field of international criminal justice as a means of justifying its work, and is unconstrained by juridical categories: it represents the «justice for everyone» that the film suggests is possible through the work of the ICC. The second figure, the «juridified victim», is the product of a legal framework that must necessarily narrow who may appear as a victim according to jurisdictional forms, whether tied to temporality, location, or subject matter. Only certain kinds of crimes can be adjudicated before the ICC, and the exercise of prosecutorial discretion to act in certain situations and in relation to certain individuals narrows the field even further.

Both figures of victimhood appear within the text of the Rome Statute: the general or abstract as well as the narrower legal construct. The statute's preamble notes that «during this century millions of children, women and men have been victims of unimaginable atrocities that deeply shock the conscience of humanity», drawing a link between historical victims of mass atrocities and the institutional redress that the ICC seeks to offer the abstract victim in the present. More narrowly, the Statute offers specific provisions for victim participation: to make representations to the Pre-Trial Chamber when the prosecutor requests proprio motu for an investigation to be authorised [art. 15(3)]; to submit observations regarding a jurisdictional challenge

\footnotetext{
1 For an account of this «legacy talk» at the International Criminal Tribunal for Rwanda, see KENDALL, S. and NouwEN, S., "Speaking of Legacy: Toward an ethos of modesty at the International Criminal Tribunal for Rwanda», American Journal of International Law, vol. 110, 2016, pp. 212-232.

2 Kendall, S. and Nouwen, S., «Representational Practices at the International Criminal Court: The Gap between Juridified and Abstract Victimhood», Law and Contemporary Problems, vol. 76, 2013, pp. 235-262.
} 
to the Court or on the admissibility of a case [art. 19(3)]; and to express views and concerns at stages in the proceedings that the Court deems appropriate [art. 68(3)]. Forms of redress are enshrined through reparations provisions (art. 75) and through the establishment of an independent Trust Fund for Victims (art. 79) providing reparations and other forms of assistance.

These provisions are unique in the history of international criminal tribunals. While participatory roles for victims have been written into the foundational texts of internationalised courts, such as the Extraordinary Chambers of the Courts of Cambodia and the Special Tribunal for Lebanon, these institutions exist in a relationship with civil law systems that include practices of victim participation or representation, whether as a special chamber of a national court structure or as an international tribunal drawing upon municipal law. Previous international criminal tribunals — such as the post-World War II tribunals in Nuremberg and Tokyo and the UN-backed tribunals for Rwanda and the former Yugoslavia - have included victims solely as witnesses, drawing them into proceedings as bearers of evidence rather than as participants in their own right. In this way the Rome Statute sought to establish a supra-national role for victims across civil and common law traditions within the institutional space of the ICC, a development which has been hailed by victims' rights advocates and regularly invoked by ICC personnel as a central feature of the Court's work.

Although these provisions are unique, they arise out of a broader history of attempts to institutionalise victims' rights within the framework of international criminal justice. The international criminal tribunals for Rwanda and the former Yugoslavia had been criticised for inadequately addressing the interests of individuals and communities who had experienced grave crimes, and a coalition of non-governmental organisations advocated on behalf of these constituencies during the drafting of the Rome Statute. The ICC based its incorporation of principles on previous international law efforts to establish an architecture of victims' rights through the 1985 UN General Assembly Declaration of the Basic Principles of Justice for the Abuse of Power $^{3}$. Yet the system established in Rome in 1998 left many open questions concerning how the provisions would be institutionalised at the ICC. Further rounds of negotiations regarding the Court's Rules of Procedure and Evidence attempted to address how they would be implemented, and much was left to the determination of ICC judges in pre-trial proceedings and during trials ${ }^{4}$. As a consequence of this openness, the resulting jurisprudence has varied according to chamber, and individuals may receive different treatment as victim participants based upon which situation or case they fall under. Ef-

\footnotetext{
3 Clarke, K. recounts this history in "We ask for justice, you give us law": The rule of law, economic markets, and the reconfiguration of victimhood», in DE Vos, C., KENDALL, S. and STAHN, C. (eds.), Contested Justice: The Politics and Practice of International Criminal Court Interventions, Cambridge, Cambridge University Press, 2015, pp. 272-301.

4 See generally Mcgonigle LeYh, B., Procedural Justice? Victim Participation in International Criminal Proceedings, Cambridge, Intersentia, 2011, pp. 225-335.
} 
forts to institutionalise procedural rights and reparations for conflict-affected individuals have been routed through a juridical framework that focuses on retribution as its primary objective.

In this regard, the implementation of victims' rights at the ICC is distinct from other forms of humanitarian practice, if the "restorative turn» in international criminal law can be considered in that light ${ }^{5}$. Whereas humanitarianism generally responds to needs, international criminal law responds to wrongs that may have resulted in individual harms. As a consequence, the link to the criminal act remains central for many dimensions of the ICC's «victim mandate». The main aspects of the Court's work in this area include participation by court-recognised victims at various points in the trial proceedings, as well as support from the Trust Fund for Victims, which entails forms of assistance throughout the trial process as well as the prospect of reparations following conviction.

The nexus to a charged crime features most prominently in relation to victim participation. As charges are dropped in specific cases due to inadequate evidence - or indeed if entire cases are dropped, as happened in the Kenyan situation - the status of a court-recognised victim participant can shift from a case-specific victim to that of a broader situation, with a corresponding loss of participatory rights. Even where individuals are afforded participatory rights, these must be balanced against the rights of the accused, and victims are not considered parties to the proceedings as they are in some civil law systems. Participation can be quite limited in practice and is usually mediated through a legal representative who may act on behalf of a large number of individuals. Due to limited resources as well as security concerns, some victim representatives have faced challenges accessing the individuals on whose behalf they act. Furthermore, some individuals applying for formal recognition as victim participants have waited long periods of time to hear back from the Court and may not understand the technical legal reasons underlying their rejected applications. Whilst the nexus to a charged crime is significant from a legal perspective, it may be less so to conflict-affected individuals seeking redress.

The reparative dimension of the ICC's work conducted through the independent Trust Fund for Victims is less bound up with juridical categories and links to charged crimes, but it is still carried out with some judicial oversight that may constrain its activities. For example, whilst the Fund may contribute to physical rehabilitation, psychological rehabilitation, and material support in ICC situation countries, in the situation of the Democratic Republic of Congo there is no physical rehabilitation mandate because it was not originally requested from the governing chamber. Furthermore, decisions about

5 See Kendall, S., «Beyond the restorative turn: The limits of legal humanitarianism», in DE Vos, C., Kendall, S. and Stahn, C. (eds.), op. cit., note 3, pp. 352-376; and Kendall, S. and Nouwen, S., "International Criminal Justice and Humanitarianism», Oxford Handbook on International Criminal Law (forthcoming 2019). 
targeting prioritise conflict-related harms that reflect the crimes within the Rome Statute rather than broader needs of particular communities. This is what makes the Trust Fund's assistance distinct from the work of other humanitarian organisations, manifesting a turn to restorative justice in the field of international criminal law, and it lends a new dimension to the ambitions and practices of a predominantly punitive legal field.

There are many commendable aspects of this turn to forms of justice beyond the punitive, and proponents of victims' participatory and reparative rights have remained in dialogue with the ICC to refine and improve the implementation of Rome Statute provisions ${ }^{6}$. This treaty was shaped in part through advocacy on behalf of conflict-affected communities, not only as a broader negotiation between adversarial and inquisitorial legal systems, but also as a way of institutionalising a different form of accountability; namely, accountability to individuals and communities who have suffered most from grave crimes. Yet the ambition articulated in the Court's commemorative film - to seek «justice for everyone»- is located within two broader contexts, political and legal, that enframe and constrain its possibilities for victim redress. The ICC's selective geographies of intervention, cognisable within the terms of political realism, bear upon who may receive reparations and assistance: within the Democratic Republic of Congo, for example, but not in Syria. Legally, the Court is constrained by familiar jurisdictional forms such as time, place, definition of the crime, and the territory on which it is enacted. At the time of writing, Israeli Defense Force personnel's lethal use of force against protestors in Gaza raises questions of whether the ICC prosecutor may look further into these events following on a previous referral for alleged crimes on Palestinian territory. Yet accountability for individuals associated with strong states remains a political struggle at the international level, informing the limits to this alternative conception of accountability that victims of grave crimes may claim. As with humanitarianism and human rights more broadly, victim redress at the ICC remains within a terrain of political and legal constraints that should be thought together with its restorative potential.

Keywords: victims, restorative justice, international criminal law, humanitarianism.

Palabras clave: víctimas, justicia restaurativa, Derecho internacional penal, humanitarismo.

6 The various actors and reports are too numerous to mention here, but one illustrative example is the International Federation for Human Rights (FIDH) report, Five Myths about Victim Participation in ICC Proceedings, Report No. 649a, December 2014. Available at: $h t t p s: / / w w w . f i d h . o r g / I M G / p d f / c p i 649 a$. $p d f$ (this website has been accessed 15 May 2018). 